Boise State University

ScholarWorks

Communication Faculty Publications and

Presentations

Department of Communication

$4-1-2015$

Making the Case for War: A Comparative Analysis of CNN and BBC Coverage of Colin Powell's Presentation to the United Nations Security Council

Seth Ashley

Boise State University 


\title{
Making the Case for War: A Comparative Analysis of CNN and BBC Coverage of Colin Powell's Presentation to the United Nations Security Council
}

\author{
Seth Ashley \\ Boise State University
}

\begin{abstract}
The normative role of journalism in democracy is well established: Democracy depends on news media to facilitate self-government. But theories of the press point to structural limitations that inhibit the democratic ideal. To examine this contradiction, this article offers a comparative analysis of online news coverage by CNN and BBC of Colin Powell's speech to the United Nations Security Council on Feb. 5, 2003. Ethnographic content analysis is used to examine the coverage and to consider each outlet's broad institutional context. The article concludes that structural limitations are less of a hindrance at the BBC, which is better situated to enhance rational-critical dialogue and democratic self-governance through inclusion of a greater diversity of sources and a wider array of opinion.
\end{abstract}

Keywords: Iraq war, Colin Powell, public sphere, CNN, BBC, ownership, comparative, critical, framing

On February 5, 2003, United States Secretary of State Colin Powell appeared before the United Nations Security Council to lay out evidence that Iraq was in violation of U.N. resolutions and to make the case for possible military action. On behalf of the Bush Administration, Powell set out to prove to the world that Saddam Hussein posed an imminent threat due to his continued efforts to develop weapons of mass destruction despite UN demands to the contrary. The speech now represents an infamous and pivotal moment in the Bush Administration's march toward the invasion of Iraq on March 20, 2003 (Dadge and Schechter, 2006).

Despite Powell's apparent failure to convince more than a handful of international leaders and observers, the presentation to the Security Council did increase public support for the war effort in the United States (Zarefsky, 2007) and helped pave the way for an invasion on the grounds that Saddam Hussein possessed weapons of mass destruction, was pursuing a weapons development program and was linked to Al Qaeda terrorists who attacked the United States on September 11, 2001 (Kull et al., 2003).

Much of the evidence presented by Powell was later revealed to be based on faulty intelligence and ungrounded assertions. According to rhetoric scholar David Zarefsky, "The fatal flaw in the speech was the unreliability of key evidence. More critical questioning of evidence at the time could have brought this problem to light and perhaps have avoided some of the consequences that followed" (Zarefsky, 2007: 275). Even Powell himself has called the speech "painful" and said that it represents a "blot" on his record (Weisman, 2003). Nevertheless, the speech captured the attention of the international community and took on a dominant role in the public sphere through widespread coverage in the international news media.

The historical significance of this moment inspires the present inquiry into international news media coverage of the Powell speech at the U.N. Broadly, this inquiry centers on questions regarding the role of the news media in democratic societies and their critical function, especially when deciding whether to go to war. Self-governance is only possible with an independent press, but theories of the press point to structural limitations that inhibit the democratic ideal. To examine this contradiction, this study examines the range of debate offered in CNN and BBC online coverage of the Powell speech and looks for similarities and differences. The comparison is motivated by an attempt to account for these similarities and differences based on an understanding of each organization's structure and function in its respective culture. An ethnographic content analysis is employed to carry out the comparison and to inform larger discussions about news media’s ability to serve democracy. 


\section{Literature Review}

The condition of U.S. public opinion during the run-up to the Iraq war is well documented and often repeated. As large numbers of Americans came to hold misperceptions about Iraq, support grew for an invasion (Bennett et al., 2007; Kull et al., 2003; Patterson, 2013). Like Americans, people in other countries also falsely believed that Iraq possessed weapons of mass destruction but, unlike Americans, held diverse views about what should be done. American support for the war effort crystalized well before the initial invasion; British support came more slowly, and only after the invasion did a majority approve. Support eventually melted in both countries but did so much more quickly in Britain than the U.S. (Everts and Isernia, 2005).

In the ensuing decade, countless reasons have been given for these gaps between perception and reality, and the news media have been regularly implicated for their role in dispensing and perpetuating these misrepresentations. Democratic theory has long rested on the notion that an informed public is a necessary ingredient for a selfgoverning society, so it makes sense to consider the role of news media in their ability to perform the essential task of informing citizens.

\section{The Sphere of Legitimate Controversy: Who Decides?}

While an open idea marketplace may be the ideal vision for a democratic media, it has proven to be far from the reality. In deciding what becomes news, journalists are bound by standards and conventions that dictate what issues may "legitimately" be discussed. Daniel Hallin (1986) organizes the world of information media into three realms: consensus, deviance, and the divide between. Consensus and deviance are the comfortably agreed upon categories for ideas that must either be respected and celebrated or challenged and condemned, according to Hallin. In between is the "sphere of legitimate controversy," which in the U.S. is defined primarily by the two-party system and is where objectivity and balance reign supreme. But when the sphere of legitimate controversy is closed to ideas or individuals that are on the outskirts of acceptability, news media cannot expect to do more than maintain the status quo. And when it comes to military conflict, the sphere of controversy need not offer anything more. As J. Herbert Altschull has written, "When the United States is in collision with another nation, it is not necessary to give equal attention to both sides to the dispute; to do so is to be unpatriotic" (1995: 68). The chilling effects of nationalism became an especially pertinent issue following the terrorist attacks of Sept. 11, 2001, and the ensuing conflict in Afghanistan.

These notions are consistent with Bennett's “indexing” hypothesis, which suggests that the press serves primarily to represent the dominant voices of power to the extent that they exist and that public opinion follows that representation (Bennett, 1990, 2012). "The overriding norm of contemporary journalism seems to involve compressing public opinion (at least law-abiding, legitimate opinion) to fit into the range of debate between decisive institutional power blocs" (Bennett, 1990: 124-125). Bennett calls this an "ironic twist on the democratic ideal" in that "modern public opinion can be thought of as an 'index' constructed from the distribution of dominant institutional voices as recorded in the mass media" (Bennett, 1990: 125). Iraq war coverage provides a fine opportunity to examine the range of debate offered by news media as a test of the indexing hypothesis. In an effort to help explain gaps between media representations and reality, it is also worth considering the array of factors that might contribute to the production of an indexing effect or of a shrunken sphere of legitimate controversy.

\section{The Press and the Public Sphere}

Jurgen Habermas (1989) has described the rise and fall of the "bourgeois" public sphere, which initially flourished, beginning in the 17th century, as public forums gained autonomy from state control and as literacy spread following the Renaissance and concurrent with the Age of Enlightenment. But conditions changed as capitalism took root in the 1800s and the bourgeois public sphere floundered. By this time, the press "could abandon its polemical stance and concentrate on the profit opportunities for a commercial business. In Great Britain, France, and the United States at about the same time (the 1830s) the way was paved for this sort of transition from a press that took ideological sides to one that was primarily a business" (Habermas, 1989: 184). Today, it is argued that the commercial function of the press and a depoliticized culture of consumerism often exert great influence on news media content (See Shoemaker and Reese, 1996; Herman and Chomsky, 1988; McChesney, 2008) and preclude news media outlets from facilitating rational-critical debate or from providing an open public forum, especially in the United States. 
Theories of framing, gatekeeping and agenda-setting reveal the news media's ability to propagate certain constructions of reality. Scholars have also written about the illusion of objectivity (See Bagdikian, 2004; Lippmann, 1922), which provides journalism with an aura of scientific positivism at the expense of more comprehensive views of reality. Herbert Gans (1979) offered a landmark ethnography in his Deciding What's News, in which he describes the embedded values that often guide journalists' work. Values such as ethnocentrism and the preservation of social order are seldom overt in news products but are often present. Ultimately these studies represent only a portion of media scholarship, but the views are well represented in communication research, and the range of influences on media producers is well documented.

This range of influences may obscure the need for the critical function of the press and hamper the media's ability to carry it out. Indeed, many have argued that pressures such as these led the U.S. news media to neglect their central functions in the months prior to the Iraq war by failing to provide independent, fact-based reporting that would challenge false or unsupported claims made by government officials and other powerful interests (Dadge and Schechter, 2006; Boyd-Barrett, 2004; Christie, 2006).

Research on British media performance is mixed. One report found that media outlets in Britain tended to focus on government statements favoring the case for war at the expense of dissenting views (Robinson et al., 2009). Another study found that the BBC was less likely to air views that challenged the case for war than were other British television outlets (Lewis, 2004). As Justin Lewis has written about the BBC's Iraq war coverage, "far from revealing an anti-war BBC, our findings tend to give credence to those who criticised the BBC for being too sympathetic to the government in its war coverage" (Lewis, 2003: np). BBC critics on the left have historically suggested that the organization too often supports the positions of government (See MacCabe and Stewart, 1986; Born, 2005).

Other reports found evidence that British media—especially the BBC—did a better job of providing a critical forum and conveying dissenting views (Ravi, 2005; Schechter, 2003). "Of all analyzed media, only the BBC maintained an equilibrium of sorts of positive and negative coverage, mostly remaining ambivalent in tone, with far fewer explicitly positive or negative statements than its German or U.S. counterparts” (Mock and Rettich, 2003: 270). News programs in the US were said to have relied heavily on reports of military actions without any serious debate as to their purpose. "To escape the patriotic sheen, viewers had to turn to other media outlets, foremost the BBC" (Mock and Rettich, 2003: 276). Apparently bias is in the eye of the beholder.

Journalism and Democracy in the U.S.

The normative role of journalism in the U.S. democracy is well established: Democracy depends on news media to facilitate self-government. But just as the media marketplace can become homogenized at the hands of a few corporate owners (See Bagdikian, 2004; McChesney, 1999), the idea marketplace can become closed to the diverse views that democracy demands.

The dearth of news media autonomy and independence seen after 9/11 occurred at the confluence of commercial and cultural pressures. Coverage of the conflicts in Afghanistan and Iraq were subject to pressures imposed by the commercial media system, and these pressures are tied to cultural influences. For example, Walter Issacson of CNN issued memos to reporters covering the war in Afghanistan that described the limitations on what could be covered (Jamieson and Waldman, 2003). Issacson has said he received calls from corporate leaders saying that CNN was being unpatriotic. CNN's policy became to balance images of Afghanistan with reminders of 9/11. In a commercial advertiser-supported media system, it may be unrealistic to expect any mainstream media outlet to go out on a limb and make its own case against war when there is no significant public debate or debate in Washington.

As with the conflict in Afghanistan, the media also faced severe limitations on access as they attempted to cover the war in Iraq (Brandenburg, 2007). The military allowed physical access to the battlefield through the process of embedding journalists, which achieved the goal of avoiding official censorship but also severely limited what journalists were allowed to see and cover. But more significantly, this de facto censorship was not challenged in the media. Rather, research suggests that the press was more than willing to go along with official reports (BoydBarrett, 2004). 
This is an author-produced, peer-reviewed version of this article. The final, definitive version of this document can be found online at Media, War \& Conflict, published by SAGE. Copyright restrictions may apply. doi: 10.1177/1750635214541031

The New York Times famously issued an apology for its own poor coverage of Iraq. The work of Judith Miller and other Times reporters was heavily criticized for its role in "acting as a conduit for stories originating in US military and intelligence agencies” (Boyd-Barrett, 2004: 438). Journalists like Miller tended to take their cues about the newsworthiness of stories from Washington officials. If there is no debate in Washington, there is no debate in the media (Lewis \& Rose, 2002). As Oliver Boyd-Barrett noted, “The NYT’s own apologia strongly suggests that an overall 'corporate' point of view was imposed on Iraq war coverage. Many of the identified weaknesses must be laid at the door of very senior personnel, people we can reasonably expect to represent whatever key interests lie behind the newspaper" (Boyd-Barrett, 2004: 444).

Other examples of how outside forces manipulated coverage of the war abound, including an order by Cumulus Media that its radio stations broadcast only positive stories about the war, the firing of Peter Arnett by NBC because of a broadcast from Iraq, and the cancellation of The Phil Donahue Show by MSNBC out of fear that the show would overemphasize an anti-war viewpoint (Demaske, 2005). And at smaller media outlets, reporters have been reprimanded and even fired for participating in anti-war activities or speaking out against the war. Legal protections for media owners allow this sort of silencing of opinion. "Hence, the legal system's protection of the free press based on these professional norms leads not to more open debate in the marketplace of ideas but to a market-driven system that shuts down public debate in the name of corporate profits and denies journalists their constitutional rights of free speech as private citizens” (Demaske, 2005: 132-33).

In a striking difference between US and British media coverage of the run-up to the war, the now famous Downing Street Memo revealed the administration's plan to invade Iraq despite a total lack of intelligence that would justify military action. The story of the memo was first reported in the London Sunday Times and then covered widely in the British press. The memo, however, was largely neglected in mainstream US news media, where the story would have posed a major threat. "As the story threatened to reach a critical mass, the U.S. media's novel set of news paradigm repair tactics morphed into the creation of a dominant construct surrounding the DSM-in effect, a rewriting of history" (Bicket and Wall, 2007: 219). This example illustrates the confluence of power structures that can lead to the marginalization of dissent even when based on factually sound evidence.

\section{Public Broadcasting and the British Media System}

Since its creation in 1927 when it was nationalized under a royal charter, the British Broadcasting Company has claimed a public service mission, aiming to elevate cultural standards. The BBC's first director-general, John Reith, "saw the BBC as an opportunity to raise the knowledge, morals, and taste of the British public" (Starr, 2004: 341). Financed by licensing fees and largely protected from political influence, the BBC model served as the world's primary alternative to a commercial approach to broadcasting.

Americans were not keenly aware of the varying systems as they emerged elsewhere in the world; by the 1930s, insofar as the issue was debated at all, both the critics and the defenders of American commercial radio contrasted it with the British public-service model. These two institutional paradigms were widely seen as the fundamental alternatives for broadcasting in the Englishspeaking world (Starr, 2004: 330).

In Britain, public service broadcasting had a solid footing, benefited from public support and gained a complete monopoly over broadcasting from the 1920s until the 1950s. The BBC retained a commitment to public service even after the introduction of commercial radio and television. Regulations made it difficult for commercial broadcasters to dominate the market and established standards requiring them to serve the public interest. "In short, commercial principles were kept on a short leash and were not permitted to set the rules for the entire system" (McChesney, 1999: 249).

Income from the licensing fee increased during the 1960s and 1970s as the number of households in the U.K. grew and those households upgraded from black-and-white to more expensive color television licenses. The fee leveled off in the 1970s and, in 1991, was cut three percent and linked to inflation. Low growth and increasing costs required the BBC to begin to consider funding alternatives (Küng, 2000). Recently, the BBC is said to have wavered under commercial pressures. "By the 1990s, British media scholar Colin Sparks announced that British broadcasting was a predominantly commercial affair, and that the BBC was taking rather than giving cues" (McChesney, 1999: 249). Technological and regulatory changes paved the way for commercialism to take root. 
This is an author-produced, peer-reviewed version of this article. The final, definitive version of this document can be found online at Media, War \& Conflict, published by SAGE. Copyright restrictions may apply. doi: 10.1177/1750635214541031

As a result of these cultural, technological and regulatory shifts, public broadcasting in Britain and outside the U.S. generally has given way to commercial pressures, and public broadcasters have had increasing difficulty as they attempt to make the case for their subsidies. "What was once the U.S. exception is becoming the global rule" (McChesney, 2004: 247). As one director-general of the BBC put it,

"The accusation is that the BBC is too successful, too powerful and too competitive. This is one of the few jobs where you get crap for losing and crap for doing well” (quoted in McChesney, 2004: 247-48).

Over its long history, the BBC has faced both criticism and praise for its relationship with and coverage of the British government. In the 1930s, American commercial radio "offered a far greater diversity of political opinion than was available in Europe at the time. The BBC during the interwar period severely restricted political debate" (Starr, 2004: 376). More recently, the BBC has been praised for its independence from government in its coverage of the continuing war in Iraq even as other British media outlets have been criticized for a lack of autonomy (Robinson et al., 2009).

Today, the BBC remains the strongest public broadcasting institution in the world. Compared to National Public Radio and the Public Broadcasting Service in the US, Britain devotes more than 50 times more per capita in public funds to the BBC (McChesney, 2007: 215). Scholars point out that the long-established licensing fee and the culture it perpetuates are the central reasons for the BBC's ability to produce what is often considered to be high quality content (Küng, 2000). This creates a somewhat different media culture for Britain generally compared to what is present in the United States.

\section{Comparing CNN and the BBC}

Around the time of the 2003 invasion of Iraq, CNN and the BBC were considered to be "the two leading players in the Anglo-Saxon media world” (Küng, 2000: 3). CNN.com and BBC.com (also known as BBC.co.uk) were the two most highly visited non-aggregator news websites on the Internet according to the web statistics company Alexa Internet (alexa.com). Both sites are major news sources in their respective countries and abroad.

Founded in 1980 by Ted Turner under the umbrella of the Turner Broadcasting System, CNN first became profitable in 1985 and emerged as a serious competitor to traditional broadcast networks during its 1991 Gulf War coverage. This coverage is said to have established the lucrative market for 24-hour news that dominates the cable television market today. CNN.com debuted in 1995. In 1996, the Turner Broadcasting System merged with Time-Warner, which remains its parent company. Today Time-Warner is one of the world's largest media conglomerates and enjoys annual revenues of more than $\$ 44$ billion.

Compared to the BBC, CNN has a very different organizational and institutional structure. In some ways, CNN's independence from government funding is said to yield certain advantages. "Receiving no public subsidy, CNN is not answerable in the way public service broadcasters are to political forces, apart from needing to comply with national regulations governing broadcasting” (Küng, 2000: 115). On the other hand, even CNN managers and journalists acknowledge that there is a different type of influence that accompanies the commercial funding model. "CNN exists, like the BBC, to serve its public, but the balance of power is different. At CNN, viewers have the upper hand, they dictate, they know best—even if programme-makers personally hold different views...” (Küng, 2000: 155). This analysis suggests that viewer control of news content is synonymous with commercial or advertiser control. If the news outlet must secure funding primarily through advertisers, then its goal is to deliver a large news audience. Ultimately, the advertiser sets the agenda. This is quite different from the public broadcasting model.

Broadly, the British and American media systems are often considered to be quite similar when compared to the rest of the world. Both systems enjoy relatively similar press freedom and legal restrictions, and both systems exist within relatively similar market economies. Both systems fall within Hallin and Mancini’s (2004) conceptualization of the "North Atlantic or Liberal" media system model, even though these scholars acknowledge the dissimilarities. "The British and American media systems (which we will discuss as examples of the Liberal Model) are in fact quite different in many ways, even though it is common to talk about the Anglo-American model of journalism as though it were singular" (Hallin and Mancini, 2004: 11). In one of the central differences, Britain is dominated by a national or super-regional press, whereas the U.S. is dominated by local newspapers. This is significant because 
national newspaper markets "tend to produce a more politically differentiated press" (Hallin and Mancini, 2004: 25). Readership is also a factor. In 2000, newspaper sales per 1,000 adults reached 408.5 in the U.K. while the U.S. level was only 263.6 (Hallin and Mancini, 2004: 23). By 2007, those numbers had declined to 307.98 for the U.K. and 212.63 for the U.S. (World Association of Newspapers, 2008: 40-43). With regard to television, public broadcasting in general receives a much larger audience share in the U.K. at 39 percent compared to the U.S. at just 2 percent, based on figures from 2000 (Hallin and Mancini, 2004: 42). In 2008, the BBC audience share was 38 percent (Benson \& Powers, 2009). By 2014, that number had fallen slightly to 35.9 (Broadcasters' Audience Research Board, 2014). In the 2012-2013 season, public television in the U.S. averaged 1.43 in primetime Nielsen ratings (PBS, 2013).

Ultimately, as Hallin and Mancini note, the organizational and institutional structure of the BBC and its long history helps to set the British media system apart. "The professional model [for the governance of public broadcasting] is exemplified above all by the British Broadcasting Corporation (BBC), where a strong tradition developed that broadcasting should be largely insulated from political control and run by broadcasting professionals” (Hallin and Mancini, 2004: 31).

The foregoing literature suggests that—although no comparison is perfect—-the British and American media systems are well suited to comparative analysis, especially when looking directly at the largest and most pervasive news organizations in each country as they covered a key news event in the run-up to the 2003 Iraq war. Thus, this study seeks to address the following research questions:

RQ1: What was the range of debate offered in coverage by CNN and BBC of Colin Powell's speech to the United Nations Security Council?

RQ2: What similarities and differences are evident in coverage by CNN and BBC, and how might they be explained by institutional structure and control?

\section{Method}

In attempting to address these questions, this study takes a comparative look at the content produced by major news outlets in the U.S. and Britain. Comparative analysis is useful here because it helps to reveal disparities in coverage and helps to highlight elements that might be present in one media system or outlet and not in the other. "In a time of globalization, one might even argue that the choice not to conduct a piece of research cross-nationally requires as much justification as the choice to conduct cross-national research” (Livingstone, 2003: 478).

Through ethnographic content analysis (Altheide, 1996), this study uses a purposive cluster sample of articles from CNN.com and BBC.com posted from Feb. 2, 2003 through Feb. 8, 2003, three days before and after Powell's speech at the UN. BBC.com published 16 original articles during the week under examination; CNN.com published 21. Articles from CNN were gathered using Lexis-Nexis. Articles from BBC were gathered using Google News because Lexis-Nexis did not offer original BBC.com content as a source. To maintain a narrow focus, a series of search terms were used: Iraq, Colin Powell, United Nations and weapons of mass destruction.

Ethnographic content analysis (Altheide, 1996) employs the principles of qualitative data collection and analysis in its approach to the study of documents. ECA is a sociological approach that takes a holistic view of news content and is similar to other qualitative approaches, such as framing, discourse or narrative analysis. With ECA, the focus is on a document's context and meaning. "Interest is not primarily in the immediate impact of messages on some audience member, but rather two aspects of the document: (a) the document process, context and significance and (b) how the document helps define the situation and clarify meaning for the audience member” (Altheide, 1996: 12).

ECA leans heavily on grounded theory (Glaser and Strauss, 1967), but as Altheide notes, the grounded approach is more oriented toward theory development whereas ECA aims for clear description. ECA has been applied in a variety of contexts, from news coverage of the Columbine school shooting (Altheide, 2009), popular discourse about religion (Healey, 2010), coverage of the American war on drugs (Jernigan and Dorfman, 1996), the socio-cultural context of concussions in sports (McGannon et al., 2013), and news coverage of the Iraq war (Altheide and Grimes, 2005; Zollmann, 2011). 
With ECA, the process of reflexively analyzing documents begins by developing a familiarity with the process and context of the source of the information, and identifying a unit of analysis. In this case, the individual articles are those units. Next, the researcher constructs a protocol based on the emergent categories that will be used to guide data collection and analysis. The protocol is then continually tested and revised. For this study, articles were analyzed for frames, themes and discourse, and the protocol was based on several categories that emerged. The analysis of frames centered on whether the article suggested consensus about the war effort or highlighted dissent. Thematic aspects analyzed included the types of sources present in the article, the promotion or challenging of the case for war, and the presence of an Iraqi or other international point of view. Discourse was defined as supportive or critical of the U.N., the U.S. or Iraq. Under the protocol, it was possible for each article to have multiple or mixed orientations.

\section{Findings}

Dominant frames. Table 1 compares dominant frames, which were found to be oriented toward consensus or dissent. "Consensus" was represented in those articles that expressed agreement among leaders and observers, generally supported or cited support in favor of military action, and suggested that war was likely to result. Articles such as these cited official US or UK government sources making pro-war claims without providing any challenging views or sources. "Dissent" was manifest in articles that provided conflicting or alternative viewpoints and included some suggestion that war could be avoided. Articles such as these expressed the view or cited sources suggesting that the case in favor of military action might be ungrounded.

Consensus dominated the CNN article "Powell prepares multimedia speech," which detailed the mechanics Powell would use to make the case: "He will unveil video, slides and audiotapes of intelligence intercepts as evidence..." and "Powell may wear a wireless microphone so that he can stand up and move around as he speaks" (Powell prepares multimedia speech, Feb. 3, 2003). Another CNN article reported on President Bush's weekly radio address, in which he "urged the Security Council to hold its ground in demanding Iraq to disarm" because "Iraqi President Saddam Hussein is deceiving the body by failing to account for his nation's weapons of mass destruction” (Bush urges UN to get tough, Feb. 8, 2003). The consensus frame was also evident in articles that placed the burden of proof on Iraq. A CNN article quoted UN inspector Hans Blix as saying "if weapons of mass destruction do not exist, Iraq's goal should be 'to seek and present credible evidence for their absence'” (Blix looks to Iraq for 'substance,' Feb. 3, 2003).

Similarly, the BBC article "Evidence against Iraq 'unmistakable"” demonstrated agreement among government officials and described the war plans being drawn up:

UK Prime Minister Tony Blair has insisted there is unmistakable evidence that Iraq is failing to co-operate with United Nations weapons inspectors... Senior US military officials have already been outlining what they say are their plans for a military assault on Iraq. The onslaught would begin with ground attacks combined with a massive assault from the air, defence officials told the BBC (Evidence against Iraq ‘unmistakable,’ Feb. 3, 2003).

Consensus also dominated a Feb. 6 BBC article that described how Powell's testimony was well received on Capitol Hill (Senators back Powell, Feb. 6, 2003) and another in which UK Defence Secretary Geoff Hoon asserted that the UK “would be willing to use nuclear weapons” (UK restates nuclear threat, Feb. 2, 2003).

Dissent was expressed in such articles as CNN's “Saddam denies 'relationship' with al Qaeda” or BBC's “Leaked report rejects Iraqi al-Qaeda link." The dissent frame dominated articles where government officials were able to express alternative views. For example: "Saddam said his government does not have any weapons of mass destruction or ties to the al Qaeda terrorist network” (Saddam denies 'relationship' with al Qaeda, Feb. 4, 2003). Dissent was also evident when non-official sources offered competing views, such as a CNN article that quoted Shelagh Foreman, director of Washington-based Peace Action: "II feel as Americans we feel we need to speak out about what we believe,' Foreman said. 'I think that is what a democracy is about'” (Peace Action: Not everyone is spoiling for a fight, Feb. 3, 2003). Similarly, a BBC article noted that Iran's Foreign Minister, Kamal Kharrazi, "stressed the need for a diplomatic solution and for arms inspectors to be given more time" (Iran strives to avoid Iraq war, Feb. 6, 2003). 
Overall, the BBC offered a relative balance between consensus (44\%) and dissent (56\%), whereas CNN articles were more likely to feature the consensus frame (71\%) over the dissent frame (29\%).

Dominant sources. Table 2 details the types of sources that dominated the articles. Categories included US official, UK official, Iraqi official, international official and non-official sources. This comparison is significant because it suggests whether the news outlet focused primarily on the views of one source category or offered a diversity of viewpoints. US officials such as Bush, Powell, Condoleezza Rice and a handful of US senators dominated the CNN articles (62\%), whereas only 25\% of BBC articles relied on US officials, mainly Bush and Powell. UK officials such as Blair and Hoon appear in 31\% of BBC articles and none of the CNN articles. Iraqi officials (such as Saddam Hussein, Gen. Amer al-Saadi and Ambassador Mohammed Aldouri) or international officials (such as UN inspector Hans Blix and Chinese Foreign Minister Tang Jiaxuan) appeared in 25\% of BBC articles and 19\% of CNN articles. CNN featured only one article with a non-official source (Shelagh Foreman of Peace Action), while BBC offered three articles featuring non-official sources (Andrew Murray of the Stop the War Coalition, several professors from Johns Hopkins University's School of Advanced International Studies, and protestors at the US embassy in Bangkok).

Overall, the BBC offered a more balanced range of sources from each category, including a greater number of foreign officials and war protesters.

Dominant discourse. Table 3 examines dominant discourse in each of the news articles. Dominant discourse was classified by an article's overall level of support or criticism expressed on behalf of the UN or the US. Discourse was also defined by whether the article emphasized cooperation by the Iraqi government with the UN, weapons inspectors and foreign leaders. Because discourse types varied within some articles, articles could fall into more than one category.

For an example of cooperative discourse, the BBC article "Saddam 'optimistic' about avoiding war" offers the view of former UK MP Tony Benn, who met with Saddam during a fact-finding mission to Baghdad. Benn "saw it as an opportunity to 'explore' alternatives to military conflict" and that he felt he had to go "because a lot of people in the world would like to know if there is an alternative to war and that is what I am exploring" (Saddam 'optimistic' about avoiding war, Feb. 2, 2003). Another BBC article demonstrated support for the UN in quoting Iran's Foreign Minister, Kamal Kharrazi, who "has said another UN Security Council resolution on Iraq would be 'helpful' and has again stressed the importance of avoiding force to settle the crisis” (Iran strives to avoid Iraq war, Feb. 6, 2003).

A CNN article offered a critique of the US based on an interview with Peace Action director Shelagh Foreman, who "said she does not believe the Bush administration is working closely enough with the international community, which includes some nations urging restraint in dealing with Iraq." However, CNN balanced the critique with statements of support, such as this one, three paragraphs later: "The Bush administration, of course, sees this differently, and has repeatedly said that Iraq poses a threat to the United States and the rest of the world" (Peace Action: Not everyone is spoiling for a fight, Feb. 3, 2003).

Overall, CNN was found to include views that were more supportive (57\%) than critical (10\%) of the US, whereas the BBC offered a balance of views that supported (38\%) and criticized (31\%) the US. The BBC offered more support for the UN (50\%) compared to CNN (19\%), and CNN seemed to stress Iraqi non-cooperation (43\%) slightly more than did the BBC (31\%).

Themes. Tables 4 and 5 list all of the articles analyzed for this study and their publication dates. The tables show the overlap in themes for each article. Articles that featured more than one theme could fall into more than one category. Of the BBC articles, $50 \%$ included an emphasis on the case for war, whereas $71 \%$ of CNN articles did this. BBC articles almost always offered a challenge to the case for war (94\%) compared to CNN (38\%). BBC articles were also more likely to express an Iraqi point of view (38\% for BBC, $19 \%$ for CNN) or the point of view of a source from another country (38\% for BBC, $29 \%$ for CNN).

For example, a BBC article challenging the case for war described the dissenting opinions among European Union nations, particularly Greece, which called for an emergency summit (Greece bids for Iraq emergency summit, Feb. 5, 2003). Another article includes both an emphasis on and a challenge to the case for war, as it opens with US Defense Secretary Donald Rumsfeld saying "Iraq has to be tackled” but three paragraphs later quotes the German 
This is an author-produced, peer-reviewed version of this article. The final, definitive version of this document can be found online at Media, War \& Conflict, published by SAGE. Copyright restrictions may apply. doi: 10.1177/1750635214541031

foreign minister saying he was "simply not convinced” by the arguments for war (Rumsfeld says Iraq action is vital, Feb. 8, 2003). CNN articles that offered a challenge to the case for war generally centered on a direct challenge by Iraq itself (Iraq: Powell evidence untrue, Feb. 5, 2003) or another international actor (China stands firm on Iraq action, Feb. 3, 2003). BBC articles that emphasized the case for war also included a challenge, while most of the CNN articles that emphasized the case for war did not include alternative views.

CNN offered a greater number of pro-war statements by US officials, and any dissenting views that were included were balanced disproportionately with official statements. Dissenting views by US Democrats in Congress were addressed perfunctorily as when one sentence is devoted to Senator Joe Biden's suggestion that Powell seek the support of members of the Security Council (Powell takes Iraq argument to senators, Feb. 6, 2003). The focus in most CNN articles was on Powell's evidence and Iraq's response. Reports detail support from US officials. Responses from other countries were mainly oriented toward the impending vote by the UN Security Council (which never happened) and international involvement in US plans for military action. The Iraq-Al Qaeda link was referenced often by CNN (Powell: Iraq hiding weapons, aiding terrorists, Feb. 5, 2003; Powell's key points on Iraq, Feb. 5, 2003; Saddam denies 'relationship' with al Qaeda, Feb. 4, 2003), but was presented in the context of factual statements by Colin Powell or Condoleezza Rice or in the context of denials of the link by Saddam Hussein or Iraqi Ambassador Mohammed Aldouri. One article detailed plans for how the war effort will likely be carried out through the use of Turkish military bases (U.S. in talks with Kurds, Feb. 6, 2003).

The BBC was far more likely to reflect views critical of the war effort and to publish statements challenging the case for war. In the article "Blair defends al-Qaeda claim" (Feb. 5, 2003), the report begins by expressing Prime Minister Tony Blair's belief that ties existed between Iraq and al Qaeda, but the article emphasizes that Blair "admitted that he did not know how deep these go.” The BBC also reported on a leaked British intelligence report that rejected the Iraq-al Qaeda link (Leaked report rejects Iraqi al-Qaeda link, Feb. 5, 2003). The BBC also seemed to emphasize dissenting views from Members of Parliament, from foreign leaders (Chirac, Mandela, Greek officials, etc.), and from international activists such as Thai Muslims. The BBC also included dissenting views from within the US, such as those of US college students (US students debate Iraq, Feb. 6, 2003). The BBC also highlighted the threat posed by North Korea and its possession of nuclear weapons as potentially more significant that the Iraqi threat. The BBC also presents Powell's speech as an attempt to sell skeptical Americans and members of Congress, whereas CNN frames the story in a way that suggests that world leaders are prepared to accept Powell's arguments.

Interestingly, both the BBC and CNN made a comparison to U.S. Ambassador Adlai Stevenson's speech to the U.N. in 1962 during the Cuban Missile Crisis. In "Powell prepares multimedia speech" (Feb. 3, 2003), CNN framed Powell's speech as just as important and stirring as Stevenson's much anticipated presentation. In “Americans weigh Iraq evidence" (Feb. 5, 2003), the BBC downplayed similarities to the Stevenson speech, pointing out that the Powell speech had a far weaker impact and received no live television coverage on US broadcast networks.

Overall, this analysis reveals a more international and critical orientation by the BBC and a more ethnocentric and pro-state orientation by CNN. The notable difference expressed in the tables above is the presence of some sort of dissenting view in nearly every BBC article while the majority of the CNN articles took a one-sided pro-war approach. Generally, the BBC included a wider diversity of sources and offered a range of dissenting views as well as a tone of skepticism. CNN primarily represented a pro-American view, relying heavily on the statements of the Bush Administration and pro-war members of Congress. The BBC tended to facilitate discussion of the strength or weakness of Powell's evidence while CNN did not, and the BBC seemed to seek a greater diversity of sources and give minor attention to statements of US officials except for the evidence presented by Powell.

\section{Discussion}

Democracy is possible only with an informed public. But theories of the press point to structural limitations that inhibit the democratic ideal. To examine this contradiction, this article compared online news coverage by CNN and BBC of Colin Powell's speech to the U.N. Security Council on Feb. 5, 2003. If self-government relies on diversity of opinion and viewpoint, the BBC seemed to do a better job of performing its democratic function than CNN in this one-week sample of online news coverage surrounding Powell's speech. The range of debate within individual BBC articles was broader and more varied than that of CNN articles, demonstrating a more limited sphere of legitimate controversy for CNN and a clear example of the indexing effect in that no major institutional voices sought to challenge the case for war. The BBC might be better positioned to resist the indexing effect or at least to include a 
This is an author-produced, peer-reviewed version of this article. The final, definitive version of this document can be found online at Media, War \& Conflict, published by SAGE. Copyright restrictions may apply. doi: 10.1177/1750635214541031

broader array of institutional voices in its index. This is consistent with previous research that suggests that British journalists generally are less deferential and more antagonistic to office holders than their American counterparts (Bicket and Wall, 2009). This foregoing analysis combined with a consideration of broader institutional differences seems to point toward two main forces as being capable of influencing news content.

First and foremost is the difference in funding models. Despite regulatory and technological changes over recent decades, the BBC generally continues to enjoy relative freedom from commercial interests and pressures. CNN, on the other hand, is more likely to allow market forces to influence news coverage and content. The BBC seems to be able to act more independently of government and politics than does CNN, which seems more likely to follow the lead of official US government sources at the expense of diverse viewpoints. The BBC seems more likely to challenge official sources and present competing views in a more balanced context. Thus, the public service broadcasting model with its long history seems to enhance the quality of the journalism produced.

The other major influence here seems to be cultural. The BBC enjoys a long history and tradition of independence from commercial pressures accompanied by a clear public service mission. CNN, on the other hand, emerged and prospered in the context of competitive market forces and a focus on live, 24-hour news. For both networks, cultural and institutional forces clearly converge as they exert their influence on news coverage and content. From this small study, it seems that the BBC is somewhat more capable of facilitating the rational-critical debate that democracy demands.

It is important to note that this analysis is based on an admittedly small sample and that it is not possible to make broad conclusions about the institutional orientations of an entire nation's media system based on a small sample from a single news outlet. Clearly, a multitude of factors can potentially influence news media content provided by any news outlet within any media system. However, even though the political, legal and economic systems within which American and British media exist are quite similar, cultural and institutional forces seem to be somewhat different. Specifically, CNN and the BBC are quite different with regard to organizational, institutional and cultural elements, and some of these differences seem to be evident in the small sample of online news articles reviewed here. Future studies and policies should consider these influences on news content and work to minimize forces that limit debate on all issues that affect society but particularly on issues of war and peace, of life and death.

\section{References}

Altheide, D L (1996) Qualitative Media Analysis. Thousand Oaks: Sage Publications.

Altheide, D L (2009) The Columbine shootings and the discourse of fear. American Behavioral Scientist 52(10): 1354-1370.

Altheide, D L \& Grimes, J N (2005) War programming: The propaganda project and the Iraq war. The Sociological Quarterly 46(4): 617-643.

Altschull, J H (1995) Agents of Power: The Media and Public Policy. White Plains, NY: Longman.

Bagdikian, B H (2004) The New Media Monopoly. Boston: Beacon Press.

Bennett, W L, Lawrence, R G \& Livingston, S (2007) When the Press Fails. Political Power and the News Media from Iraq to Katrina. Chicago: University of Chicago Press.

Bennett, W L (1990) Toward a theory of press-state relations. Journal of Communication 40(2):103-125.

Bennett, W L (2012) News: The Politics of Illusion. New York: Longman.

Bicket, D \& Wall, M (2007) Circling the wagons: Containing the impact of the Downing Street Memo story in the United States. Journal of Communication Inquiry 31(3): 206-221.

Bicket D \& Wall, M (2009) BBC News in the United States: a 'super-alternative' news medium emerges. Media, Culture \& Society 31(3): 365-384.

Born, G (2005) Uncertain Vision: Birt, Dyke and the Reinvention of the BBC. New York: Vintage.

Boyd-Barrett, O (2004) Judith Miller, the New York Times, and the propaganda model. Journalism Studies 5(4): 435-449.

Brandenburg, H (2007) Security at the source: Embedding journalists as a superior strategy to military censorship. Journalism Studies, 8(6): 948-963.

Broadcasters’ Audience Research Board (2014) Channel viewing share. Available at http://www.barb.co.uk/viewing/trend-graph-channel-viewing-share.

Christie, T B (2006) Framing rationale for the Iraq War: The interaction of public support with mass media and public policy agendas. International Communication Gazette, 68 (5-6): 519-532. 
This is an author-produced, peer-reviewed version of this article. The final, definitive version of this document can be found online at Media, War \& Conflict, published by SAGE. Copyright restrictions may apply. doi: 10.1177/1750635214541031

Dadge, D \& Schechter, D (2006) The War in Iraq and Why the Media Failed Us. Westport, Conn.: Praeger Publishers.

Demaske, C (2005) The market place of ideas? Global implications of market-driven US media. International Journal of Media \& Cultural Politics, 1(1): 131-136.

Everts, P \& Isernia, P (2005) The polls—-trends: The war in Iraq. Public Opinion Quarterly 69(2): 264-323.

Gans, H (1979) Deciding What's News: A Study of CBS Evening News, NBC Nightly News, Newsweek and Time. New York: Vintage.

Glaser, B G \& Strauss, A L (1967) The Discovery of Grounded Theory: Strategies for Qualitative Research. Chicago: Aldine Publishing Company.

Habermas, J (1989) The Structural Transformation of the Public Sphere: An Inquiry into a Category of Bourgeois Society. Cambridge, Mass.: MIT Press.

Hallin, D C (1986) The Uncensored War: The Media and Vietnam. Berkeley, CA: University of California Press.

Hallin, D C \& Mancini, P (2004) Comparing Media Systems: Three Models of Media and Politics. Cambridge, UK: Cambridge University Press.

Healey, K (2010) The pastor in the basement: Discourses of authenticity in the networked public sphere. Symbolic Interaction 33(4): 526-551.

Herman, E S \& Chomsky, N (1988) Manufacturing Consent: The Political Economy of the Mass Media. New York: Pantheon Books.

Jamieson, K H \& Waldman, P (2003) The Press Effect: Politicians, Journalists, and the Stories That Shape the Political World. Oxford: Oxford University Press.

Jernigan, D \& Dorfman, L (1996) Visualizing America's drug problems: An ethnographic content analysis of illegal drug stories on the nightly news. Drug Problems 23(2): 169-196.

Kull, S, Ramsay, C \& Lewis, E (2003) Misperceptions, the media, and the Iraq war. Political Science Quarterly 118(4): 569-598.

Küng, L (2000) Inside the BBC and CNN: Managing Media Organisations. New York: Routledge.

Lewis, J (July 4, 2003) Biased broadcasting corporation. The Guardian. Available at http://www.theguardian.com/news/2003/jul/04/comment.

Lewis, J (2004) Television, public opinion and the war in Iraq: The case of Britain. International Journal of Public Opinion Research 16 (3): 295-310.

Lewis, D A \& Rose, R P (2002) The President, the press, and the war-making power: An analysis of media coverage prior to the Persian Gulf war. Presidential Studies Quarterly, 32(3): 559-70.

Lippmann, W (1922) Public Opinion. New York: Harcourt, Brace \& Co.

Livingstone, S (2003) On the challenges of cross-national comparative media research. European Journal of Communication 18(4): 477-500.

MacCabe, C \& Stewart, O (eds.) (1986) The BBC and Public Service Broadcasting. Manchester: Manchester University Press.

McChesney, R (1999) Rich Media, Poor Democracy: Communication Politics in Dubious Times. Urbana: University of Illinois Press.

McChesney, R (2004) The Problem of the Media: U.S. Communication Politics in the Twenty-First Century. New York: Monthly Review Press.

McChesney, R (2007) Communication Revolution: Critical Junctures and the Future of Media. New York: New Press.

McChesney, R (2008) The Political Economy of Media: Enduring Issues, Emerging Dilemmas. New York: Monthly Review Press.

McGannon, K R, Cunningham, S M \& Schinke, R J (2013) Understanding concussion in socio-cultural context: A media analysis of a National Hockey League star's concussion. Psychology of Sport and Exercise 14(6): 891-899.

Mock, R \& Rettich, M (2003) The war against Iraq on television: A split reality. In: Schechter, D (ed.) Embedded: Weapons of Mass Deception: How the Media Failed to Cover the War on Iraq. Amherst, N.Y.: Prometheus Books.

Patterson, T E (2013) Informing the News: The Need for Knowledge-Based Journalism. New York: Random House. PBS (March 2014) PBS Overview. Available at http://www.pbs.org/about/background/

Ravi, N (2005) Looking beyond flawed journalism: How national interests, patriotism, and cultural values shaped the coverage of the Iraq war. Harvard International Journal of Press/Politics, 10(1): 45-62.

Robinson P, Goddard P \& Parry K (2009) U.K. media and media management during the 2003 invasion of Iraq. American Behavioral Scientist 52(5): 678-688. 
Schechter, D (2003) Embedded: Weapons of Mass Deception: How the Media Failed to Cover the War on Iraq. Amherst, N.Y.: Prometheus Books.

Shoemaker, P J \& Reese, S D (1996) Mediating the Message: Theories of Influences on Mass Media Content. White Plains, N.Y.: Longman.

Starr, P (2004) The Creation of the Media: Political Origins of Modern Communications. New York: Basic Books.

World Association of Newspapers (2008) World Press Trends. Available at http://www.wan-ifra.org/

Weisman, S R (Feb. 6, 2003) Threats and responses: Security Council; Powell, in U.N. speech, presents case to show Iraq has not disarmed. The New York Times. Available at http://www.nytimes.com/2003/02/06/world/threats-responses-security-council-powell-un-speech-presentscase-show-iraq-has.html

Zarefsky, D (2007) Making the case for war: Colin Powell at the United Nations. Rhetoric \& Public Affairs 10(2): 275-302.

Zollmann, F (2011). Managing the elite consensus: A critical analysis of press discourses over warfare in Iraq. Global Media and Communication 7(3): 263-268.

\section{Tables}

Table 1. Dominant Frames

\begin{tabular}{|l|l|l|}
\hline & Consensus Frame & Dissent Frame \\
\hline BBC & $7(44 \%)$ & $9(56 \%)$ \\
\hline CNN & $15(71 \%)$ & $6(29 \%)$ \\
\hline
\end{tabular}

Table 2. Dominant Sources

\begin{tabular}{|l|l|l|l|l|l|}
\hline & US official & UK official & Iraqi official & $\begin{array}{l}\text { International } \\
\text { official }\end{array}$ & Non-official \\
\hline BBC & $4(25 \%)$ & $5(31 \%)$ & $4(25 \%)$ & $4(25 \%)$ & $3(19 \%)$ \\
\hline CNN & $13(62 \%)$ & $0(0 \%)$ & $4(19 \%)$ & $4(19 \%)$ & $1(5 \%)$ \\
\hline
\end{tabular}

Table 3. Dominant Discourse

\begin{tabular}{|l|l|l|l|l|l|l|}
\hline & $\begin{array}{l}\text { Supportive of } \\
\text { UN }\end{array}$ & $\begin{array}{l}\text { Critical of } \\
\text { UN }\end{array}$ & $\begin{array}{l}\text { Supportive } \\
\text { of US }\end{array}$ & $\begin{array}{l}\text { Critical } \\
\text { of US }\end{array}$ & $\begin{array}{l}\text { Iraqi } \\
\text { cooperation }\end{array}$ & $\begin{array}{l}\text { Iraqi non- } \\
\text { cooperation }\end{array}$ \\
\hline BBC & $8(50 \%)$ & $2(13 \%)$ & $6(38 \%)$ & $5(31 \%)$ & $6(38 \%)$ & $5(31 \%)$ \\
\hline CNN & $4(19 \%)$ & $5(24 \%)$ & $12(57 \%)$ & $2(10 \%)$ & $6(29 \%)$ & $9(43 \%)$ \\
\hline
\end{tabular}


Table 4. BBC Articles

\begin{tabular}{|c|c|c|c|c|c|}
\hline & & $\begin{array}{l}\text { Emphasizes case } \\
\text { for war }\end{array}$ & $\begin{array}{l}\text { Challenges case } \\
\text { for war }\end{array}$ & $\begin{array}{l}\text { Expresses } \\
\text { Iraqi point } \\
\text { of view }\end{array}$ & $\begin{array}{l}\text { Expresses } \\
\text { international } \\
\text { point of view }\end{array}$ \\
\hline $\begin{array}{l}\text { Iraq 'seeks progress' in } \\
\text { arms talks }\end{array}$ & Feb 2 & & $\mathrm{x}$ & $\mathrm{x}$ & \\
\hline $\begin{array}{l}\text { Saddam 'optimistic' } \\
\text { about avoiding war }\end{array}$ & Feb 2 & & $\mathrm{x}$ & $\mathrm{x}$ & \\
\hline $\begin{array}{l}\text { UK restates nuclear } \\
\text { threat }\end{array}$ & Feb 2 & $\mathrm{x}$ & $\mathrm{x}$ & $\mathrm{x}$ & \\
\hline $\begin{array}{l}\text { Evidence against Iraq } \\
\text { 'unmistakable' }\end{array}$ & Feb 3 & $\mathrm{x}$ & $\mathrm{x}$ & $\mathrm{x}$ & $\mathrm{x}$ \\
\hline $\begin{array}{l}\text { Saddam denies links to } \\
\text { terrorists }\end{array}$ & Feb 4 & & $\mathrm{x}$ & $\mathrm{x}$ & \\
\hline $\begin{array}{l}\text { Leaked report rejects } \\
\text { Iraqi al-Qaeda link }\end{array}$ & Feb 5 & & $\mathrm{x}$ & $\mathrm{x}$ & $\mathrm{x}$ \\
\hline $\begin{array}{l}\text { Greece bids for Iraq } \\
\text { emergency summit }\end{array}$ & Feb 5 & & $\mathrm{x}$ & & $\mathrm{x}$ \\
\hline $\begin{array}{l}\text { Powell takes Iraq case } \\
\text { to UN }\end{array}$ & Feb 5 & $\mathrm{x}$ & $\mathrm{x}$ & & \\
\hline $\begin{array}{l}\text { Blair defends al-Qaeda } \\
\text { claim }\end{array}$ & Feb 5 & $\mathrm{x}$ & $\mathrm{x}$ & & \\
\hline UK sets Iraq deadline & Feb 5 & $\mathrm{x}$ & $\mathrm{x}$ & & \\
\hline $\begin{array}{l}\text { Americans weigh Iraq } \\
\text { evidence }\end{array}$ & Feb 5 & $\mathrm{x}$ & $\mathrm{x}$ & & \\
\hline $\begin{array}{l}\text { Thai Muslims rally } \\
\text { against Iraq war }\end{array}$ & Feb 6 & & $\mathrm{x}$ & & $\mathrm{x}$ \\
\hline $\begin{array}{l}\text { Iran strives to avoid } \\
\text { Iraq war }\end{array}$ & Feb 6 & & $\mathrm{x}$ & & $\mathrm{x}$ \\
\hline $\begin{array}{l}\text { US students debate } \\
\text { Iraq }\end{array}$ & Feb 6 & & $\mathrm{x}$ & & \\
\hline Senators back Powell & Feb 6 & $\mathrm{x}$ & $\mathrm{x}$ & & \\
\hline $\begin{array}{l}\text { Rumsfeld says Iraq } \\
\text { action is vital }\end{array}$ & Feb 8 & $\mathrm{x}$ & $\mathrm{x}$ & & $\mathrm{x}$ \\
\hline TOTALS & & $8(50 \%)$ & $15(94 \%)$ & $6(38 \%)$ & $6(38 \%)$ \\
\hline
\end{tabular}


Table 5. CNN Articles

\begin{tabular}{|c|c|c|c|c|c|}
\hline & & $\begin{array}{l}\text { Emphasizes } \\
\text { case for war }\end{array}$ & $\begin{array}{l}\text { Challenges } \\
\text { case for war }\end{array}$ & $\begin{array}{l}\text { Expresses } \\
\text { Iraqi point of } \\
\text { view }\end{array}$ & $\begin{array}{l}\text { Expresses } \\
\text { international } \\
\text { point of view }\end{array}$ \\
\hline $\begin{array}{l}\text { Blix looks to Iraq for } \\
\text { 'substance' }\end{array}$ & Feb 3 & $\mathrm{x}$ & & & $\mathrm{x}$ \\
\hline $\begin{array}{l}\text { Powell prepares multimedia } \\
\text { speech }\end{array}$ & Feb 3 & $\mathrm{x}$ & & & \\
\hline $\begin{array}{l}\text { Powell says he'll offer no } \\
\text { 'smoking gun' on Iraq }\end{array}$ & Feb 3 & $\mathrm{x}$ & & & $\mathrm{x}$ \\
\hline $\begin{array}{l}\text { China stands firm on Iraq } \\
\text { action }\end{array}$ & Feb 3 & & $\mathrm{x}$ & & $\mathrm{x}$ \\
\hline $\begin{array}{l}\text { Peace Action: Not everyone } \\
\text { is spoiling for a fight }\end{array}$ & Feb 3 & $\mathrm{x}$ & $\mathrm{x}$ & & \\
\hline $\begin{array}{l}\text { Saddam denies } \\
\text { 'relationship' with al Qaeda }\end{array}$ & Feb 4 & $\mathrm{x}$ & $\mathrm{x}$ & $\mathrm{x}$ & $\mathrm{x}$ \\
\hline $\begin{array}{l}\text { Rice: Powell made } \\
\text { 'compelling' case }\end{array}$ & Feb 4 & $\mathrm{x}$ & & & \\
\hline $\begin{array}{l}\text { Gadhafi supports Iraq } \\
\text { inspectors }\end{array}$ & Feb 4 & & $\mathrm{x}$ & & $\mathrm{x}$ \\
\hline $\begin{array}{l}\text { Powell confronts Iraq at } \\
\text { United Nations }\end{array}$ & Feb 4 & $\mathrm{x}$ & & & \\
\hline $\begin{array}{l}\text { Powell: Iraq hiding } \\
\text { weapons, aiding terrorists }\end{array}$ & Feb 5 & $\mathrm{x}$ & & & \\
\hline $\begin{array}{l}\text { Iraq: Powell evidence } \\
\text { untrue }\end{array}$ & Feb 5 & & $\mathrm{x}$ & $\mathrm{x}$ & \\
\hline $\begin{array}{l}\text { Iraqi officials challenge } \\
\text { U.S. accusations }\end{array}$ & Feb 5 & & $\mathrm{x}$ & $\mathrm{x}$ & \\
\hline Powell's key points on Iraq & Feb 5 & $\mathrm{x}$ & & & \\
\hline $\begin{array}{l}\text { Lawmakers applaud Powell } \\
\text { presentation }\end{array}$ & Feb 5 & $\mathrm{x}$ & & & \\
\hline $\begin{array}{l}\text { Rym Brahimi: Iraq pledges } \\
\text { more cooperation }\end{array}$ & Feb 6 & & $\mathrm{X}$ & $\mathrm{X}$ & \\
\hline Analysis: Powell's success & Feb 6 & $\mathrm{x}$ & & & \\
\hline $\begin{array}{l}\text { Powell takes Iraq argument } \\
\text { to senators }\end{array}$ & Feb 6 & $\mathrm{x}$ & & & \\
\hline $\begin{array}{l}\text { U.S. in Iraq talks with } \\
\text { Kurds }\end{array}$ & Feb 6 & $\mathrm{x}$ & & & \\
\hline $\begin{array}{l}\text { Bush to U.N.: We will not } \\
\text { wait }\end{array}$ & Feb 6 & $\mathrm{x}$ & & & \\
\hline $\begin{array}{l}\text { China cautions Bush on } \\
\text { U.N. authority }\end{array}$ & Feb 8 & & $\mathrm{x}$ & & $\mathrm{X}$ \\
\hline $\begin{array}{l}\text { Bush urges U.N. to get } \\
\text { tough }\end{array}$ & Feb 8 & $\mathrm{x}$ & & & \\
\hline TOTALS & & $15(71 \%)$ & $8(38 \%)$ & $4(19 \%)$ & $6(29 \%)$ \\
\hline
\end{tabular}




\section{Appendix A: List of Articles Analyzed From CNN.com}

February 3, 2003 Monday

Blix looks to Iraq for 'substance'

February 3, 2003 Monday

Powell prepares multimedia speech

February 3, 2003 Monday

Powell says he'll offer no 'smoking gun' on Iraq

February 3, 2003 Monday

China stands firm on Iraq action

February 3, 2003 Monday

Peace Action: Not everyone is spoiling for a fight

February 4, 2003 Tuesday

Saddam denies 'relationship' with al Qaeda

February 4, 2003 Tuesday

Rice: Powell made 'compelling' case

February 4, 2003 Tuesday

Gadhafi supports Iraq inspectors

February 4, 2003 Tuesday

Powell confronts Iraq at United Nations

February 5, 2003 Wednesday

Powell to make case against Iraq

February 5, 2003 Wednesday

Powell: Iraq hiding weapons, aiding terrorists

February 5, 2003 Wednesday

Iraq: Powell evidence untrue

February 5, 2003 Wednesday

Iraqi officials challenge U.S. accusations

February 5, 2003 Wednesday

Powell's key points on Iraq

February 5, 2003 Wednesday

Lawmakers applaud Powell presentation

February 6, 2003 Thursday

Rym Brahimi: Iraq pledges more cooperation

February 6, 2003 Thursday

Rice: Powell made 'compelling' case on Iraq

February 6, 2003 Thursday

Analysis: Powell's success 
This is an author-produced, peer-reviewed version of this article. The final, definitive version of this document can be found online at Media, War \& Conflict, published by SAGE. Copyright restrictions may apply. doi: 10.1177/1750635214541031

February 6, 2003 Thursday

Powell takes Iraq argument to senators

February 6, 2003 Thursday

U.S. in Iraq talks with Kurds

February 6, 2003 Thursday

Bush to U.N.: We will not wait

February 8, 2003 Saturday

China cautions Bush on U.N. authority

February 8, 2003 Saturday

Bush urges U.N. to get tough

Appendix B: List of Articles Analyzed from BBC.com

Sunday, 2 February, 2003, 18:05 GMT

Iraq 'seeks progress' in arms talks

Sunday, 2 February, 2003, 19:22 GMT

Saddam 'optimistic' about avoiding war

Sunday, 2 February, 2003, 19:25 GMT

UK restates nuclear threat

Monday, 3 February, 2003, 22:08 GMT

Evidence against Iraq 'unmistakable'

Tuesday, 4 February, 2003, 23:26 GMT

Saddam denies links to terrorists

Wednesday, 5 February, 2003, 10:05 GMT

Leaked report rejects Iraqi al-Qaeda link

Wednesday, 5 February, 2003, 10:30 GMT

Greece bids for Iraq emergency summit

Wednesday, 5 February, 2003, 13:54 GMT

Powell takes Iraq case to UN

Wednesday, 5 February, 2003, 16:06 GMT

Blair defends al-Qaeda claim

Wednesday, 5 February, 2003, 19:25 GMT

UK sets Iraq deadline

Wednesday, 5 February, 2003, 21:59 GMT

Americans weigh Iraq evidence

Thursday, 6 February, 2003, 08:10 GMT

Thai Muslims rally against Iraq war

Thursday, 6 February, 2003, 20:39 GMT

Iran strives to avoid Iraq war 
This is an author-produced, peer-reviewed version of this article. The final, definitive version of this document can be found online at Media, War \& Conflict, published by SAGE. Copyright restrictions may apply. doi: 10.1177/1750635214541031

Thursday, 6 February, 2003, 23:05 GMT US students debate Iraq

Thursday, 6 February, 2003, 23:34 GMT Senators back Powell

Saturday, 8 February, 2003, 15:47 GMT Rumsfeld says Iraq action is vital 